\title{
ABSTRAKSI REFLEKTIF SISWA SEKOLAH MENENGAH PERTAMA PADA MATERI SEGIEMPAT DAN SEGITIGA
}

\author{
Ahmad Choirul Anam \\ Universitas Ibrahimy, Situbondo, Indonesia \\ choirulanam@ibrahimy.ac.id
}

Received: June 14, 2021

Revised: August 07, 2021

Accepted: August 31, 2021

\begin{abstract}
:
The purpose of this study is to determine a person's ability to perform mental activities mechanically in associating new information received with previously owned information (reconstruction) which is a reflective abstraction. The process of reconstructing the concepts of quadrilaterals and triangles by students uses the mental mechanism approach of APOS theory (interiorization, encapsulation, de-encapsulation, coordination). The process can be known by observing students and analyzing the results of student work, starting with determining 1 class to be given a mathematical ability test. 29 students were present when the math ability test was given. The results of the mathematical ability test were analyzed and then found 2 students of different sexes with moderate ability. The first student is male and the second student is female, hereinafter referred to as the research subject, then the research subject is given the task of quadrilateral and triangle. The results showed that female students had done all stages of reflective abstraction in APOS theory. So, that these students were at the level of relational understanding. Meanwhile, male students only did several stages in the reflective abstraction stage on the APOS theory so that these students were included in the level of instrumental understanding.
\end{abstract}

Keywords: Reflective Abstraction, Concept Understanding, Squares and triangles, APOS Theory.

How to Cite: Anam, A. C. (2021). Abstraksi Reflektif Siswa Sekolah Menengah Pertama pada Materi Segiempat dan Segitiga. Alifmatika: Jurnal Pendidikan dan Pembelajaran Matematika, 3(2), 107-121. https://doi.org/10.35316/alifmatika.2021.v3i2.107-121

\section{PENDAHULUAN}

Hasil koneksi positif yang menghubungkan antara pengalaman baru yang diterima dari luar dengan pengalaman yang sudah dimiliki sebelumnya disebut sebagai pemahaman (Haylock \& Cockburn, 2008). Pemahaman menjadi kunci penting yang harus dimiliki siswa untuk menumbuhkan kognitif dalam pembelajaran, terutama dalam pembelajaran matematika. Peningkatan pemahaman dalam menumbuhkan kognitif sesuai dengan salah satu tujuan pembelajaran matematika dan prinsip dalam pembelajaran. Pemahaman terhadap konsep matematika berarti membuat hubungan antara representasi mental yang dimiliki oleh siswa dengan konsep matematika yang sedang dipelajari (Barmby, Harries, Higgins, \& Suggate, 2007). Menurut Anderson (Helwig et al., 2001) konsep matematika bukan hanya ide tunggal, melainkan sebuah ide dalam struktur skema pengetahuan yang skematik. Pada pelaksanaannya, proses menumbuhkan pemahaman membutuhkan adanya kemampuan siswa yang kompleks dan meyeluruh untuk menguasai konsep matematika.

Content from this work may be used under the terms of the Creative Commons AttributionShareAlike 4.0 International License that allows others to share the work with an acknowledgment of the work's authorship and initial publication in this journal. 
Pemahaman suatu konsep yang dimiliki siswa tidak dapat diobservasi secara tepat (precise) dan tekstual. Akan tetapi, hal tersebut dapat diobservasi melalui pendekatan terhadap beberapa indikator yang digunakan dalam menganalisis pemahaman konsep tersebut. Menurut Jafar (2013), beberapa indikator tersebut, antara lain: (1) kemampuan menyebutkan definisi konsep secara tepat, (2) mengidentifikasi unsur-unsur pembangun dari suatu konsep, (3) menyebutkan sifat-sifat esensial dari suatu konsep, (4) menemukan contoh dan bukan contoh terhadap suatu konsep, (5) menerapkan konsep yang dipahami untuk mendefinisikan konsep lain yang mirip (satu genus), (6) menemukan hubungan konsep yang dipelajari dengan konsep lain yang berdekatan, dan (7) memiliki kemampuan menggunakan konsep yang dipelajari untuk menyelesaikan masalah yang saling berkaitan.

Konsep matematika secara mendasar bersifat meyeluruh dan membutuhkan penguasaan yang maksimal untuk memahaminya. Pemahaman siswa terhadap konsep matematika dalam menumbuhkan kognitifnya dapat dilakukan jika pemrosesan secara aktif terhadap suatu konsep yang dipelajari melalui serangkaian mekanisme mental yang maksimal, sehingga siswa mampu merepresentasikan setiap konsep sesuai dengan tingkat pengetahuan yang dimiliki dan menjadikanya sebagai struktur pengetahuan matematika yang skematik. Pemrosesan tersebut membutuhkan aktivitas mental yang selalu berkembang sesuai dengan tahapannya menggunakan abstraksi reflektif dalam teori pengetahuan Piaget (2014). Kemudian, teori tersebut dikembangkan oleh Dubinsky menjadi teori pemahaman APOS (Arnon et al., 2014).

Teori pemahaman APOS merupakan teori pembentukan pemahaman siswa terkait suatu konsep melalui tahapan struktur mental aksi (action), proses (process), objek (object), dan skema (scheme), sedangkan hubungan antar tahapan tersebut terdapat mekanisme mental yaitu interiorisasi (aksi-proses), enkapsulasi (proses-objek), de-enkapsulasi (objek-proses), koordinasi (proses), serta menghasilkan suatu skema yang sesuai. Teori ini berarti suatu kecenderungan siswa dalam merespon dan memahami permasalahan matematika dengan menggunakan abstraksi reflektif dalam konteks sosial dengan merekonstruksi aksi, proses, objek, dan skema dalam konsep matematika, serta dapat menerapkannya dalam sebuah skema untuk memahami suatu permasalahan dan pemecahan masalah matematika (Arnon et al., 2014). Teori ini juga dapat membantu untuk memahami mekanisme suatu abstraksi reflektif dalam menggambarkan perkembangan cara berpikir logis siswa, dan juga dapat memperluas ide dalam beberapa konsep matematika (Arnawa, 2009).

Weyer (2010) mengemukakan bahwa APOS merupakan pemahaman yang menggunakan aktivitas fisik dan mental untuk mentransformasikan objek yang didapat dari hasil interaksi dengan orang lain atau hasil rekonstruksi mental dengan objek yang sudah ada sebelumnya terkait ide matematika. Konstruksi mental tersebut melalui beberapa tahapan, yaitu aksi (action), proses (process), objek (object), dan skema (scheme). Aksi (action) merupakan suatu bentuk pemahaman tentang konsep matematika yang melibatkan transformasi mental atau fisik akibat reaksi terhadap rangsangan eksternal dengan hanya mengetahui konsep yang dipelajari berdasarkan penjelasan yang disampaikan sebelumnya, hubungan aksi menuju proses yaitu interioritasi. Proses (process) didefinisikan

Alifmatika: Jurnal Pendidikan dan Pembelajaran Matematika, Desember 2021, Vol. 3, No. 2 
sebagai bentuk pemahaman terhadap suatu konsep matematika yang melibatkan imajinasi untuk mentransformasikan objek mental sebagai aktivitas internal yang terkontrol, yang berarti bahwa pada tahapan proses ini, siswa dapat mengetahui konsep tanpa ada kegiatan eksternal atau rangsangan dari luar (koordinasi).

Objek (object) berarti tahapan pemahaman konsep matematika yang terbentuk dari penerapan kegiatan pada tahapan aksi dan proses. Tahapan ini dimaksudkan bahwa siswa dapat memahami suatu konsep matematika dengan bantuan rangsangan dari luar untuk ditransformasikan ke dalam aktivitas internal secara terkontrol. Sehingga siswa dapat memahami konsep dengan baik dan mengerti makna dari konsep tersebut, jika pada prosesnya dibutuhkan melakukan aksi mental sebelumnya maka mekanisme de-enkapsulasi dapat digunakan untuk merekonstruksi konsep tersebut supaya lebih meningkatkan pemahamannya. Tahapan terakhir adalah skema (scheme), yaitu bentuk tahapan dari pemahaman konsep yang dapat mengaitkan kegiatan aksi, proses, dan objek, serta dapat membuat skema yang lainnya. Selain itu, juga tahapan skema dapat terjadi melalui mekanisme mental yang sempurna sehingga siswa dapat memahami suatu konsep dengan baik sebagai bentuk abstraksi reflektif.

Teori pemahaman APOS yang melalui tahapan aksi, proses, objek, dan skema, dapat memberikan hasil yang baik untuk menganalisa kognitif siswa dalam memahami konsep matematika. Hal ini dikarenakan tahapan dalam teori APOS adalah terperinci dan sistematis, seperti yang dikemukakan oleh Martínez-Planell \& Cruz Delgado (2016), bahwa teori APOS dapat menganalisa konstruksi mental siswa secara detail dalam menyelesaikan masalah trigonometri dan membantu meningkatkan pemahaman konsep siswa terkait materi trigonometri. Faktanya, dalam memahami konsep matematika, setiap siswa memiliki karakter yang berbeda-beda dan konstruksi mental yang dilakukan pun memiliki tahapan yang berbeda pula, sehingga tingkat pemahaman setiap siswa juga berbeda.

Pemahaman dikategorikan oleh Skemp (2012) ke dalam 2 (dua) tingkatan. Pertama, pemahaman instrumental yang merupakan kemampuan siswa dalam menerapkan aturan yang diingat sesuai dengan pemecahan masalah tanpa mengetahui mengapa aturan tersebut berlaku. Hal ini dapat dikatakan bahwa dalam tahapan APOS, siswa hanya dapat melalui beberapa tahapan dari empat tahapan dalam teori APOS secara terpisah dan tidak terstruktur. Kedua, pemahaman relasional adalah kemampuan siswa untuk menyimpulkan aturan khusus atau prosedur dari hubungan matematis yang lebih umum. Hal ini dapat dikatakan bahwa dalam tahapan APOS siswa dapat melalui keempat tahapan dalam teori APOS secara terstruktur, sehingga siswa mampu memahami konsep secara skematik.

Terdapat banyak materi yang memuat konsep matematika, salah satunya adalah konsep bangun datar, yang termuat pada materi segiempat dan segitiga (Wijaya, T. T., Ying, Z., \& Suan, 2020; Wijaya, Dewi, Fauziah, \& Afrilianto, 2018). Konsep tersebut menjadi konsep dasar yang penting dalam geometri, setelah konsep garis dan sudut sebagai prasyarat memahami konsep selanjutnya, yaitu bangun datar yang lain maupun bangun ruang. Selain itu, ada beberapa penelitian yang menyebutkan bahwa pemahaman konsep siswa pada geometri, khususnya segiempat dan segitiga masih tergolong rendah karena belum memenuhi semua aspek dalam pemahaman konsep (Khoiri, 2014). Selain itu, hasil penelitian oleh

Alifmatika: Jurnal Pendidikan dan Pembelajaran Matematika, Desember 2021, Vol. 3, No. 2 
Badraeni juga mengungkapkan bahwa siswa mengalami kesulitan dalam mengerjakan soal terkait bangun ruang sisi datar karena siswa tidak begitu memahami materi dan konsepnya (Badraeni, N., Pamungkas, R. A., Hidayat, W., Rohaeti, E. E., \& Wijaya, 2020). Sehingga, teori APOS diharapkan dapat maksimal dalam menganalisis pemahaman siswa melalui proses abstraksi reflektif pada materi segiempat dan segitiga. Dalam penelitian ini, peneliti ingin menunjukkan hasil analisis abstraksi reflektif yang dimiliki oleh siswa sekolah menengah pertama pada materi segiempat dan segitiga berdasarkan melalui pendekatan teori APOS.

\section{METODE PENELITIAN}

Penelitian ini menggunakan penelitian kualitatif dalam bentuk deskriptif pada penjelasan hasilnya. Tujuan penelitian ini adalah untuk mendeskripsikan abstraksi reflektif siswa sekolah menengah pertama pada materi segiempat dan segitiga berdasarkan pendekatan teori APOS. APOS merupakan teori pemahaman yang menggunakan struktur mental dalam mengkontruksi suatu konsep, hal tersebut membentuk suatu abstraksi reflektif yang sesuai dalam penelitian ini. Subjek penelitian diambil dengan melakukan beberapa kegiatan, yang diawali dengan menentukan kelompok siswa dalam kelas di salah satu SMP di Surabaya. Terdapat 32 siswa dalam kelas yang sudah ditentukan, tetapi hanya hadir 29 siswa. Selanjutnya, diberikan tes kemampuan matematika (TKM) kepada 29 siswa untuk mengetahui kemampuan matematika siswa, yang kemudian dianalisis dan menunjukkan kemampuan matematika siswa yang berbeda-beda. Setelah melakukan analisis, ditemukan 2 siswa yang memiliki dengan kemampuan matematika sedang dan jenis kelamin berbeda sebagai subjek penelitian. Kedua subjek tersebut diberikan tugas segiempat dan segitiga (TSS) untuk mengetahui gambaran pemahaman konsep siswa sekolah menengah pertama pada materi segiempat dan segitiga yang ditunjukkan pada hasil pengerjaan soal.

Instrumen yang digunakan dalam penelitian ini adalah tes kemampuan matematika (TKM) untuk menentukan subjek penelitian, tugas segiempat dan segitiga (TSS) sebagai alat untuk mendapatkan data terkait proses rekonstruksi konsep siswa dalam hasil pengerjaan soal kemudian alat observasi untuk mendapatkan data tambahan melalui pedoman wawancara. Beberapa instrumen tersebut sudah divalidasi oleh ahli yang terdiri dari 10 soal TKM dan 5 soal TSS pada materi segiempat dan segitiga yang disesuaikan dengan indikator teori pemahaman APOS. Tugas segiempat dan segitiga (TSS) yang diberikan pada butir soal 1 dan 2 digunakan untuk mengetahui dan menganalisa pemahaman subjek pada tahapan aksi (interiorisasi). Butir soal 3 digunakan untuk mengetahui dan menganalisa pemahaman subjek pada tahapan proses (koordinasi). Butir soal 4 digunakan untuk mengetahui dan menganalisa pemahaman subjek pada tahapan objek (enkapsulasi dan de-enkapsulasi). Butir soal 5 yang memiliki kriteria lebih kompleks dibandingkan butir soal lainnya karena mengandung soal aplikatif dan berhubungan dengan konsep lainnya, yang digunakan untuk mengetahui dan menganalisa pemahaman subjek pada tahapan skema. Wawancara digunakan untuk memperkuat dan menambah informasi terkait data dari subjek penelitian yang tidak ditemukan pada hasil pengerjaan tugas segiempat dan segitiga (TSS).

Alifmatika: Jurnal Pendidikan dan Pembelajaran Matematika, Desember 2021, Vol. 3, No. 2 
Analisis data terhadap tugas segiempat dan segitiga (TSS) didasarkan pada hasil pengerjaan siswa pada soal yang diberikan. Untuk mendeskripsikan abstraksi reflektif siswa sekolah menengah pertama pada materi segiempat dan segitiga berdasarkan teori APOS, penelitian ini mengacu pada beberapa indikator dari teori APOS.

\section{HASIL DAN PEMBAHASAN}

Berdasarkan hasil penelitian yang didapatkan dari 29 siswa yang disajikan dalam tabel berikut.

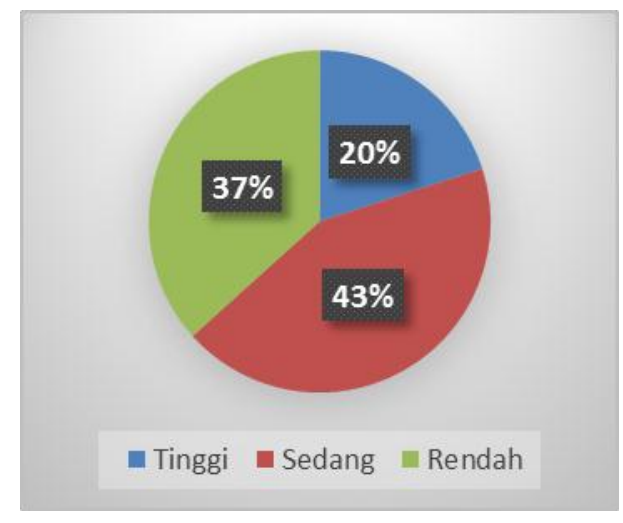

Gambar 1. Kemampuan Matematika

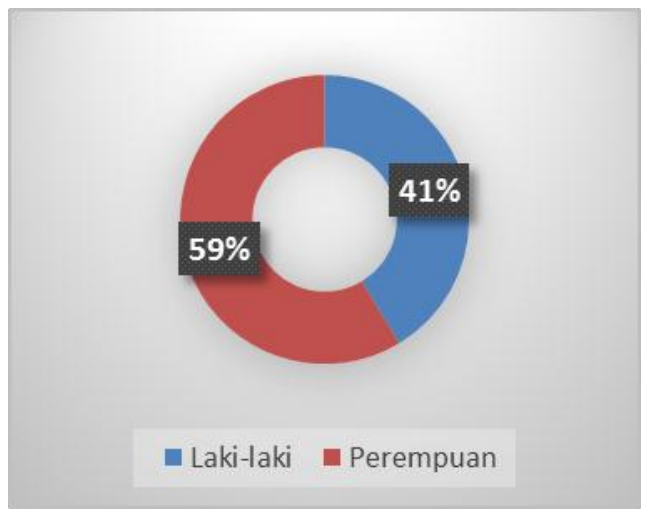

Gambar 2. Jenis Kelamin

Berdasarkan pemberian tes kepada beberapa siswa, kemudian dilakukan analisis dan ditemukan 2 siswa sebagai subjek penelitian dengan kriteria memiliki jenis kelamin berbeda dan kemampuan masing-masing sama yaitu kemampuan rendah. Sehingga terdapat 1 siswa memiliki kemampuan matematika sedang berjenis kelamin laki-laki dan 1 siswa yang lain dengan kemampuan sama dan berjenis kelamin perempuan. Berikut ditunjukkan kedua subjek penelitian yang telah dipilih berdasarkan kriteria subjek.

Tabel 1. Data Subjek Penelitian

\begin{tabular}{cccccc}
\hline No. & Inisial & Jenis Kelamin & Nilai & Kategori & Kode \\
\hline 1. & ADW & P & 82 & Sedang & PR \\
\hline 2. & MWH & L & 80 & Sedang & LK \\
\hline
\end{tabular}

Berdasarkan Tabel 1, dapat terlihat bahwa diperoleh 2 subjek penelitian yang memiliki dua kategori jenis kelamin berbeda dan kemampuan matematika sedang. Adapun subjek penelitian dengan jenis kelamin perempuan dikodekan dengan PR, sedangkan subjek penelitian dengan jenis kelamin laki-laki dikodekan dengan LK.

Berikut ditunjukkan ringkasan hasil pengerjaan pada tugas segiempat dan segitiga (TSS) serta hasil wawancara dari subjek PR dan subjek LK.

Alifmatika: Jurnal Pendidikan dan Pembelajaran Matematika, Desember 2021, Vol. 3, No. 2 


\section{Subjek Perempuan (PR)}

Pada pengerjaan soal tugas segiempat dan segitiga (TSS), subjek PR dapat menentukan unsur-unsur dalam segiempat dan segitiga dengan menuliskan semua unsur yang muncul dalam gabungan bangun segiempat maupun segitiga. Selanjutnya, subjek PR juga menuliskan semua bangun segiempat maupun segitiga sebagai pembentuk bangun yang lebih besar dan dapat menghitung jumlah keseluruhan bangun pembentuknya. Subjek PR juga dapat menghitung keliling segitiga yang ditunjukkan dalam butir soal 1 dan 2, meskipun terdapat kesalahan oleh subjek PR dalam menghitung keliling segiempat tersebut. Berdasarkan uraian tersebut, subjek PR secara umum sudah melakukan tahapan aksi dalam teri APOS (Arnon et al., 2014) dengan benar.

Pada butir soal 3, subjek PR dapat menjelaskan bangun pembentuk dari persegi panjang yang ditunjukkan dalam soal. Berikut uraian transkrip wawancara antara peneliti dengan subjek PR.

$\mathbf{P} \quad$ : Bangun apa yang ditunjukkan dalam butir soal 3?

PR : Persegi panjangyang memiliki diagonal, Pak.

$\mathbf{P} \quad$ : Setelah itu, ada berapa bangun yang terbentuk dalam gambar tersebut?

PR : 3 bangun, Pak. 1 bangun persegi panjang yang gambarnya besar. Di dalamya ada 2 bangun segitiga.

$\mathbf{P} \quad$ : Apakah 2 bangun segitiga tersebut memiliki ukuran yang sama?

PR : Iya, Pak.

$\mathbf{P} \quad$ : Mengapa ukuranya sama?

PR : Begini, Pak. Bangun tersebut 'kan awalnya persegi panjang yang memiliki diagonal. Diagonal tersebut menjadi sisi miring dari segitiga itu. Segitiga itu alas dan tingginya sama antara bangun yang atas dan bawah. Jadi, ukuranya sama.

Berdasarkan uraian transkrip wawancara di atas, dapat diketahui bahwa subjek PR memahami pertanyaan yang diberikan pada butir soal 3 dalam tugas yang diberikan. Selanjutnya, subjek PR dapat menghitung luas dari masing-masing bangun dalam gambar pada butir soal 3. Selain itu, subjek PR juga dapat menyatakan bahwa terdapat dua bangun, yaitu segiempat dan segitiga. Dengan demikian, subjek PR dapat melakukan tahapan proses dan proses mekanisme koordinasi dalam teori APOS (Arnon et al., 2014) dengan baik dan benar. Pada dua tahapan ini, karena PR sudah menunjukkan proses aksi menuju proses dengan baik, maka mekanisme interiorisasi juga dapat dikatakan baik.

Tahapan yang dapat dilakukan subjek PR selanjutnya adalah tahapan objek dalam teori APOS (Arnon et al., 2014). Hal ini dibuktikan dengan hasil pengerjaan subjek PR pada butir soal 4 sebagai berikut. 


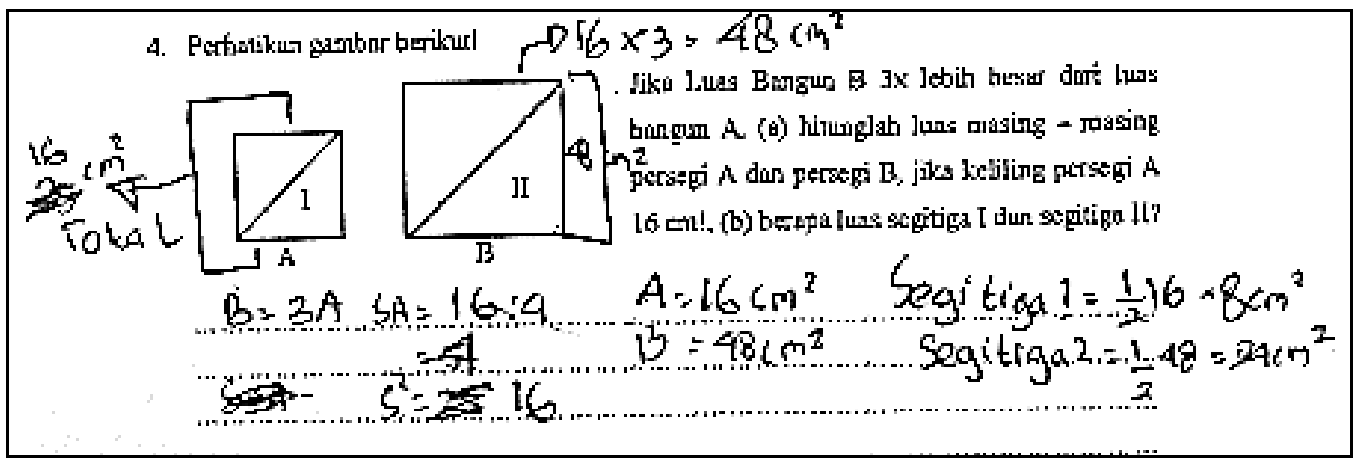

Gambar 3. Hasil Pengerjaan Subjek PR pada Butir Soal 4

Gambar di atas menunjukkan bahwa subjek PR dapat menyelesaikan soal dengan bantuan garis tanda untuk menunjukkan ukuran keliling bangun yang diketahui pada bangun I. Selanjutnya, subjek PR memberikan penjelasan dengan menunjukkan bahwa jika keliling persegi $=16 \mathrm{~cm}$, maka sisi bangun $A(S A)=16: 4=4 \mathrm{~cm}$. Karena $\mathrm{s}=4 \mathrm{~cm}$, maka untuk menghitung luas persegi $\mathrm{A}$ yakni:

$$
\begin{aligned}
L_{\square A} & =s^{2} \\
& =(4 \mathrm{~cm})^{2} \\
& =16 \mathrm{~cm}^{2}
\end{aligned}
$$

Karena diketahui $L B=3 \times L A$, maka diperoleh:

$$
\begin{aligned}
L_{\square \mathrm{B}} & =3 \times 16 \mathrm{~cm}^{2} \\
& =48 \mathrm{~cm}^{2}
\end{aligned}
$$

Karena dalam persegi tersebut dibelah menjadi 2 bagian segitiga yang sama ukuranya dan alas segitiga $=4 \mathrm{~cm}$ dan tinggi segitiga $=4 \mathrm{~cm}$, maka subjek PR menunjukkan bahwa:

$$
\begin{aligned}
L_{\Delta I} & =\frac{1}{2} \times 16 \mathrm{~cm}^{2} \\
& =8 \mathrm{~cm}^{2}, \text { yang berarti setengah dari luas segiempat A. } \\
L_{\Delta I I} \quad & =\frac{1}{2} \times 48 \mathrm{~cm}^{2} \\
& =24 \mathrm{~cm}^{2}, \text { yang berarti setengah dari luas segiempat B }
\end{aligned}
$$

Selanjutnya, peneliti melakukan wawancara dengan subjek PR untuk mengklarifikasi terkait kesesuaian antara hasil pengerjaan dengan persepsi peneliti. Berikut transkrip wawancara antara peneliti dengan subjek PR.

P : Apakah bangun A dan bangun B berbeda?

PR : Iya, Pak.

P : Mengapa berbeda? Di gambar 'kan tidak ditunjukkan ukurannya? 
PR : Iya, Pak. Memang tidak disebutkan ukurannya. Tetapi, dapat kita tahu karena di soal itu dituliskan luas bangun B adalah 3 kali luas bangun A. Jadi, jika nanti ketemu luas bangun A, maka tinggal dikalikan 3.

P : Apakah itu juga berlaku kepada bangun yang lainnya?

PR : Maksudnya, Pak?

P : Di gambar 'kan ditunjukkan ada persegi yang memiliki diagonal, maka bangun pembentuknya jika dipotong diagonalnya akan membentuk segitiga. Apakah ukuran berbeda itu juga berlaku untuk luas bangun segitiga?

PR : Berlaku, Pak.

P : Mengapa berlaku?

PR : Karena bangun yang membentuk adalah 2 buah segitiga. Jika dijumlahkan, maka akan membentuk bangun persegi. Diketahui di soal bahwa luas bangun persegi A jika dikalikan 3 maka sama dengan luas bangun A. Hal ini juga berlaku pada luas segitiga I jika dikalikan 3 hasilnya sama dengan luas segitiga $B$

P : Dalam soal diketahui bahwa keliling bangun A adalah $16 \mathrm{~cm}$. Bisa dijelaskan bagaimana perhitungan kamu dalam menjawab soal tersebut? Mengapa?

PR : Jadi, begini, Pak. Pertama, saya mencari sisi dari bangun persegi A dengan membagi kelilingnya dengan 4 karena jumlah sisinya ada 4. Selanjutnya, menghitung luasnya dengan sisi sama dengan 4, yaitu $L=s^{2}=4^{2}=16 \mathrm{~cm}^{2}$. Untuk mencari luas persegi B gampang, tinggal mengalikan16 dan 3, jadi $16 \times 3=48 \mathrm{~cm}^{2}$. Mencari luas segitiga I dengan membagi luas persegi A dengan 2, hasilnya $8 \mathrm{~cm}^{2}$. Sedangkan luas segitiga II dengan membagi luas persegi $B$ hasilnya $24 \mathrm{~cm}^{2}$, sehingga luas segitiga II adalah 3 kali luas segitiga I

Berdasarkan uraian transkrip wawancara dengan subjek PR pada butir soal 4, menunjukkan bahwa dalam memahami soal dan melakukan perhitungan untuk mencari perbandingan dan mencari luas bangun yang diinginkan soal, subjek PR dapat menjawab dengan sesuai dan alasan yang disampaikan juga rasional. Dengan demikian, subjek PR sudah melakukan tahapan objek dalam teori APOS dengan baik dan benar dan proses enkapsulasi juga sudah dilakukan PR dengan baik, sesuai dengan hasil penelitian sebelumnya (Arnon et al., 2014; Sutrisna, N., Pramuditya, S. A., Raharjo, J. F., \& Setiyani, 2021).

Kemudian, subjek PR dapat mendefinisikan butir soal 5 dengan benar. Akan tetapi, membutuhkan data tambahan untuk mengetahui maksud dari pengerjaan yang diberikan oleh subjek PR pada butir soal 5. Berikut ditunjukkan hasil pengerjaan butir soal 5 oleh subjek PR. 


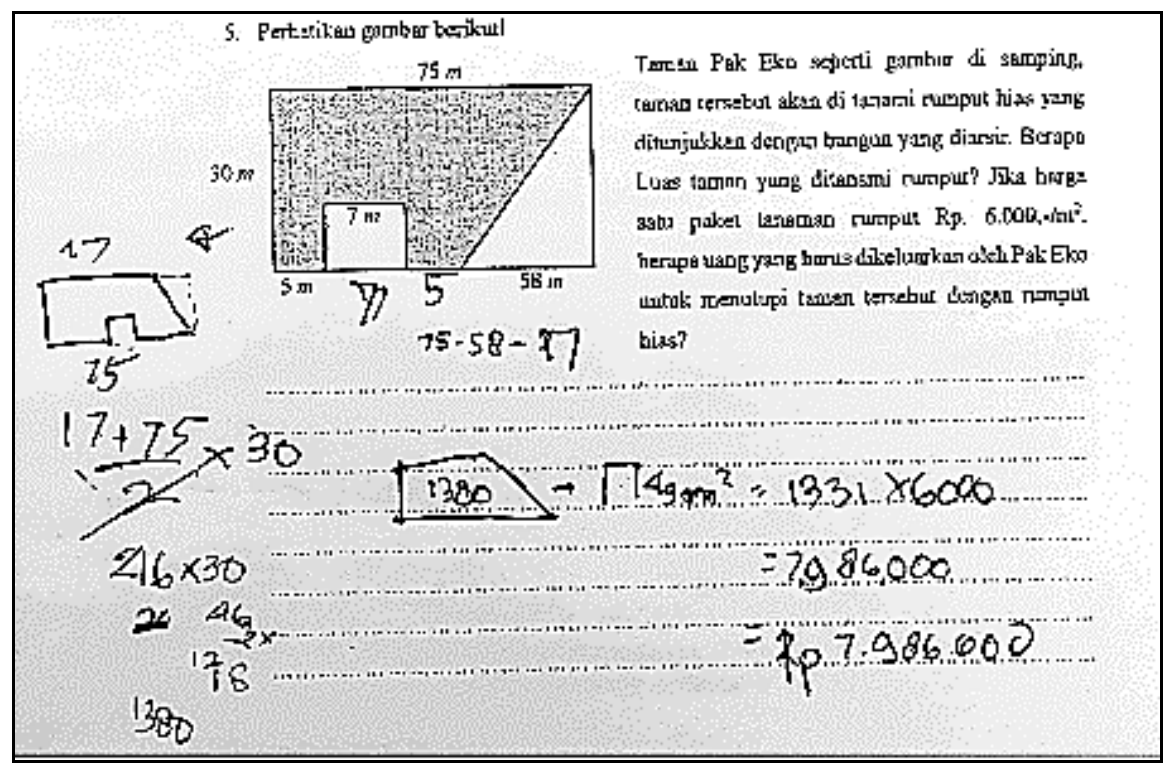

Gambar 4. Hasil Pengerjaan Subjek PR pada Butir Soal 5

Gambar 4 tersebut menunjukkan bahwa hasil akhir yang diberikan oleh subjek PR memang benar dan menggunakan bangun trapesium untuk mengetahui luas daerah yang diarsir. Akan tetapi, subjek PR tidak menunjukkan langkahlangkah yang runtut, sehingga membutuhkan data tambahan melalui wawanacara. Berikut ditunjukkan transkrip wawancara peneliti dengan subjek PR pada butir soal 5.

$\mathbf{P} \quad$ : Ada berapa bangun yang terbentuk dalam soal nomer 5? Bangun apa saja?

PR : 4, Pak. Ada persegi panjang, persegi, trapezium, dan segitiga.

P : Bagaimana proses menghitung luas daerah yang diarsir tersebut?

PR : Jadi, ada beberapa ukuran yang sudah diketahui dalam soal. Saya mencari ukuran lainnya yang belum diketahui.

P : Jika sudah diketahui ukurannya, maka selanjutnya bagaimana?

PR : Nah, kan daerah yang diarsir itu adalah luas bangun trapesium dikurangi dengan luas bangun persegi. Saya mencari luas trapesium dahulu. Saya tulis $\frac{17+75}{2} \times 30$ itu merupakan rumus trapesium. 17 adalah diagonal pertama, 75 adalah diagonal kedua, dan 30 adalah tinggi trapezium. Lalu, ketemu luas trapesium adalah $1.380 \mathrm{~m}^{2}$. Selanjutnya, mencari luas bangun persegi yaitu $s^{2}=7^{2}$ adalah $49 \mathrm{~m}^{2}$. Kemudian, $1.380 \mathrm{~m}^{2}-49 \mathrm{~m}^{2}$ hasilnya adalah $1331 \mathrm{~m}^{2}$, itu adalah luas bangun yang diarsir

P : Mengapa bisa muncul Rp. 7.986.000?

PR : Jumlah itu adalah uang yang dibutuhkan Pak Eko untuk menanami rumput. Di jawaban, saya tulis $1.331 \mathrm{~m}^{2} \times 6000$ karena soal menunjukkan 6000 setiap meter, Pak. Hasil akhirnya adalah 7.986 .000

P : Yakin dengan jawaban kamu?

PR : Yakin, Pak. 
Setelah dilakukan wawancara untuk mendapatkan data tambahan dan ditunjukkan pada transkrip wawanacara di atas, maka apat diketahui bahwa dalam pemahaman konsep pada materi segiempat dan segitiga, subjek PR dapat melakukan mekanisme enkapsulasi dan de-enkapsulasi pada tahapan proses dan objek dengan baik maka subjek sudah membangun skema konsep segiempat dan segitiga dengan baik (Arnon et al., 2014).

Berdasarkan uraian hasil tahapan-tahapan dalam teori APOS yang ditunjukkan, dapat disimpulkan bahwa subjek PR sudah melakukan semua tahapan dalam teori APOS dengan baik dan benar. Subjek PR juga dapat menjelaskan pemahaman konsep yang dimilikinya pada materi segiempat dan segitiga melalui tes pemahaman konsep yang telah dikerjakan. Dengan demikian, pemahaman yang dimiliki oleh subjek PR dikategorikan ke dalam tingkat pemahaman relasional, yang sesuai dengan Weyer (2010). Hal ini juga sejalan dengan hasil penelitian dari Anam dan Rofiki (Anam, A. C., Juniati, D., \& Wijayanti, 2019; Rofiki, I., Anam, A. C., Sari, P. E., Irawan, W. H., \& Santia, 2020).

\section{Subjek Laki-laki (LK)}

Pada tahapan aksi yang muncul dalam butir soal 1 dan 2, subjek LK dapat menyebutkan unsur-unsur dalam segitiga dan dapat menemukan semua segitiga yang membentuk bangun yang lebih besar. Subjek LK juga melakukan perhitungan untuk mencari keliling bangun yang dimaksud dalam butir soal 1 dengan tepat. Dalam butir soal 2, subjek LK tidak dapat menemukan keliling bangun yang dimaksud dengan benar, sehingga hanya dapat melakukan perhitungan pada beberapa bangun saja, meskipun sudah ditunjukkan contoh sebelumnya. Dengan demikian, subjek LK hanya melakukan tahapan aksi dalam teori APOS (Arnon et al., 2014) dengan baik, tetapi belum sepenuhnya benar.

Subjek LK dapat menjelaskan bangun pembentuk persegi panjang yang ditunjukkan dalam Gambar 3. Subjek LK dapat menemukan luas dari setiap bangun jika masing-masing bangun tersebut diuraikan. Berikut ditunjukkan hasil pengerjaan subjek LK pada butir soal 3.

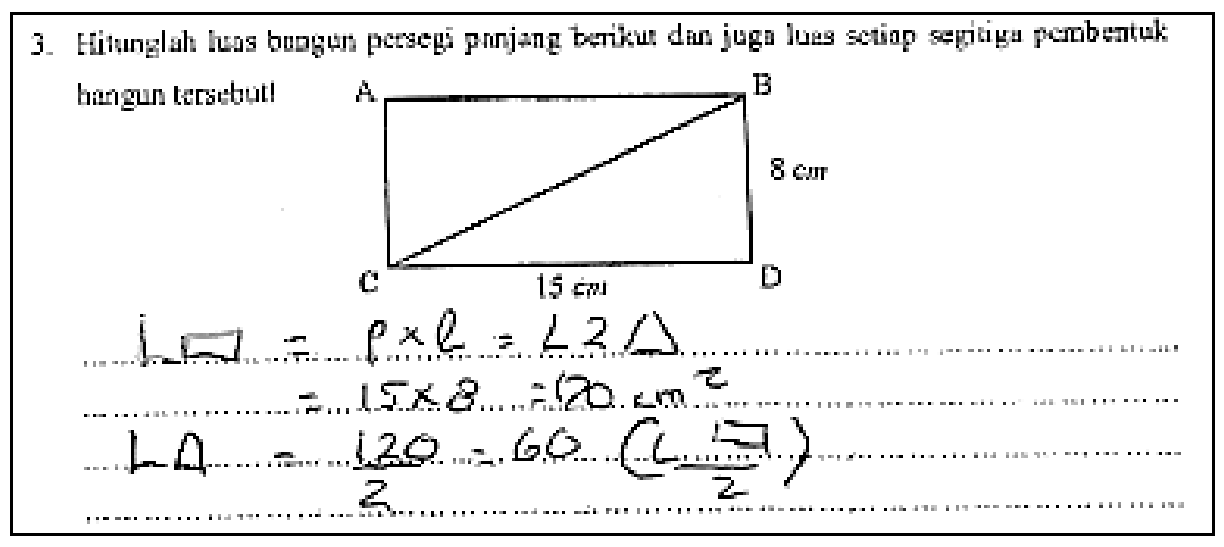

Gambar 5. Hasil Pengerjaan Subjek LK pada butir soal 3

Berdasarkan hasil pengerjaan yang ditunjukkan pada Gambar 5, terlihat bahwa subjek LK dapat menjelaskan secara tertulis bahwa bangun persegi panjang tersebut dibentuk oleh dua buah bangun segitiga dengan rincian bangun persegi

Alifmatika: Jurnal Pendidikan dan Pembelajaran Matematika, Desember 2021, Vol. 3, No. 2 
panjang dengan panjang $15 \mathrm{~cm}$ dan lebar $8 \mathrm{~cm}$. sedangkan alas segitiga $8 \mathrm{~cm}$ tingginya $15 \mathrm{~cm}$. Lebih jelasnya, peneliti melakukan wawancara dengan subjek LK, yang disajikan sebagai berikut..

$\mathbf{P} \quad$ : Bangun apa yang ditunjukkan dalam butir soal 3?

LK : Persegi panjang yang dibentuk oleh bangun segitiga, Pak.

$\mathbf{P} \quad$ : Lalu, ada berapa bangun yang terbentuk?

LK : 3 bangun, Pak. 2 bangun segitiga yang membentuk 1 persegi panjang

$\mathbf{P} \quad$ : Apakah bangun segitiga tersebut memiliki ukuran yang sama?

LK : Betul, Pak. Ukuranya sama.

P : Mengapa?

LK : Karena, jika segitiga itu saya ambil satu dulu, Pak. Kemudian saya hitung yang alasnya $8 \mathrm{~cm}$ dan tingginya $15 \mathrm{~cm}$, kan luasnya adalah $\frac{1}{2} \times 8 \times 15=60 \mathrm{~cm}^{2}$. Karena segitiga satunya juga begitu, maka luas dua buah segitiga saya kali 2 dan hasilnya $120 \mathrm{~cm}^{2}$, Pak. Nah, hasil itu sama dengan luas persegi panjang dengan $p=15 \mathrm{~cm}, l=8 \mathrm{~cm}$. $L=p \times l=15 \times 8=120 \mathrm{~cm}^{2}$. Jadi, dua segitiga tersebut ukurannya sama dan membentuk bangun persegi panjang.

Hasil transkrip wawancara di atas menunjukkan bahwa subjek LK dapat menjelaskan maksud dari persoalan pada butir soal 3 dan memahaminya. Dibuktikan dengan subjek LK dapat menjelaskan bahwa bangun tersebut dibentuk oleh dua bangun segitiga yang sama besar dan membentuk bangun persegi panjang. Subjek LK juga dapat menghitung masing-masing luasnya, sehingga terlihat bahwa subjek LK dapat melakukan tahapan proses dalam teori APOS (Mardiyah, U. R. A., \& Budiarto, 2019) dengan baik dan benar, dan juga mekanisme interiorisasi juga dapat dilakukan dengan baik.

Pada butir soal 4, subjek LK dapat membandingkan dua buah bangun persegi yang memiliki ukuran berbeda. Subjek LK juga dapat menunjukkan beberapa bangun yang ada dalam butir soal 4, serta juga dapat menghitung luasnya, meskipun hanya diketahui salah satu unsurnya. Berikut ditunjukkan hasil pengerjaan subjek LK seperti pada Gambar 6.

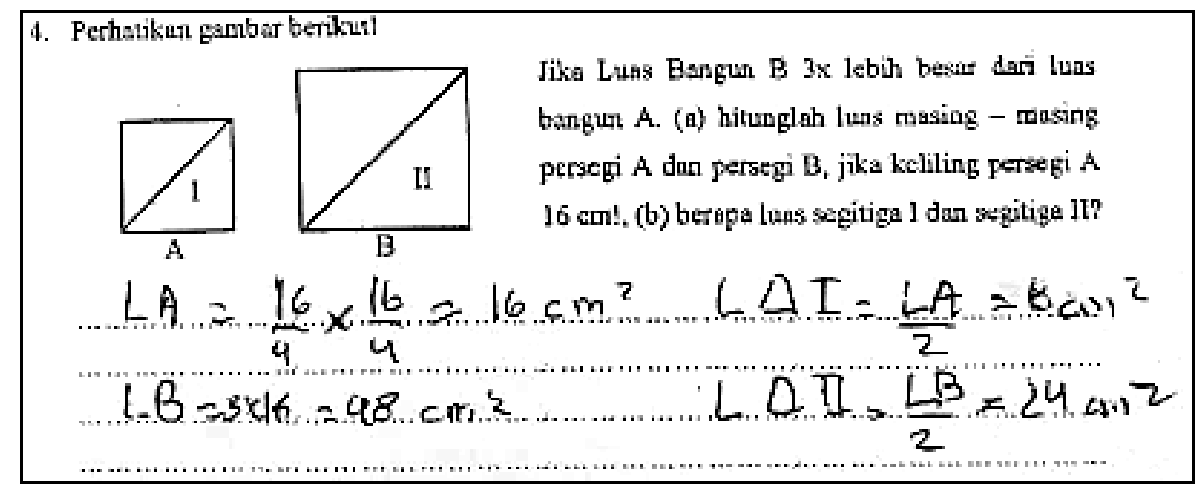

Gambar 6. Hasil Pengerjaan Subjek LK pada Butir Soal 4 
Pada Gambar 6, terlihat bahwa subjek LK dapat membandingkan dua bangun yang ditunjukkan dengan menulis pertama kali luas bangun A dengan keliling 16 $\mathrm{cm}$. Karena sisi dalam persegi ada 4, maka subjek LK mencari panjang sisinya dengan rumusan $\frac{16}{4}$ yang hasilnya sama dengan 4 . Kemudian, rumus luas persegi adalah sisi $\times$ sisi. Subjek KR menuliskan secara langsung bahwa $\frac{16}{4} \times \frac{16}{4}=16 \mathrm{~cm}^{2}$. Untuk mencari luas bangun persegi $B$, subjek LK mengalikan luas bangun A dengan 3 yang hasilnya sama dengan $48 \mathrm{~cm}^{2}$. Berdasarkan analisis pada butir soal 3 , subjek LK dapat menentukan bahwa bangun segitiga tersebut adalah dua bangun segitiga siku-siku yang memiliki ukuran sama pada masing-masing bangun A dan B. Sehingga, untuk mencari luas segitiga I, subjek LK membagi luas persegi A dengan 2 yang hasilnya $8 \mathrm{~cm}^{2}$ dan luas segitiga II adalah luas persegi B dibagi 2 hasilnya $24 \mathrm{~cm}^{2}$. Dengan demikian, subjek LK dapat melakukan tahapan objek dalam teori APOS (Arnon et al., 2014) dengan baik dan benar.

Pada tahapan terakhir dari teori APOS yaitu skema (Wulandari, E. D., Hidayanto, E., \& Rahardi, 2019), subjek LK tidak dapat melakukan tahapan skema dengan baik dan benar. Hal ini dibuktikan dengan analisa hasil pengerjaan subjek LK pada butir soal 5 yang menunjukkan bahwa subjek LK masih belum memahami persoalan dengan baik, sehingga solusi yang diberikan juga kurang tepat. Berikut gambar hasil pengerjaan subek LK pada butir soal 5.

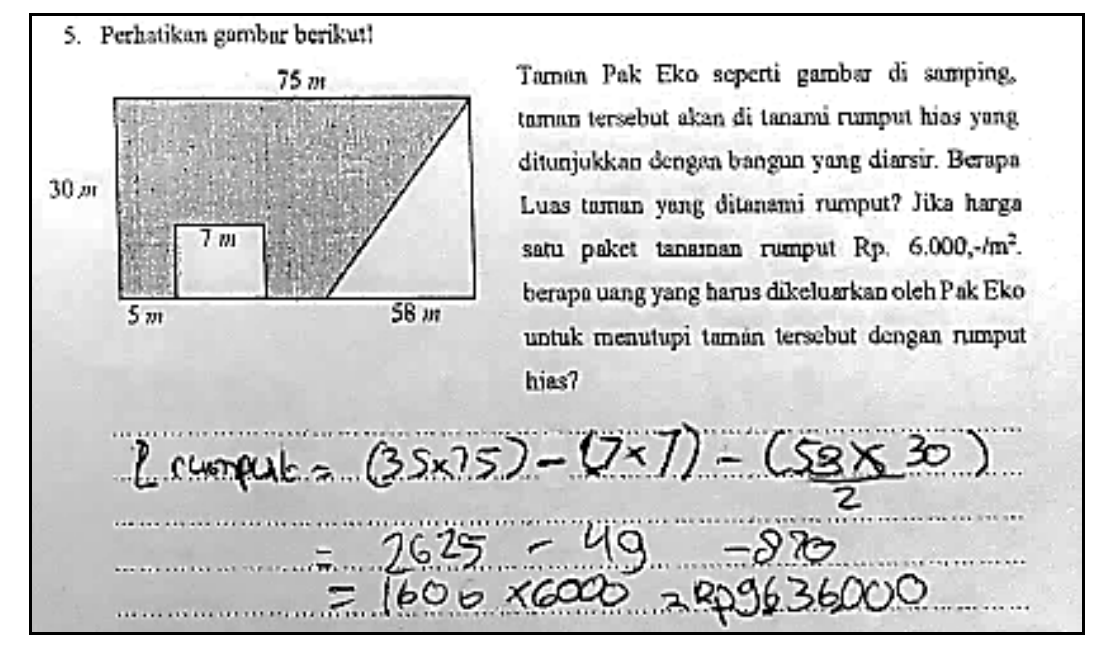

Gambar 7. Hasil Pengerjaan Subjek LK pada Butir Soal 5

Gambar 7 menunjukkan bahwa pada hasil pengerjaan subjek LK terdapat kesalahan dalam menghitung luas persegi panjang. Berdasarkan hasil pengerjaan tersebut, subjek LK memahami bahwa bangun yang diarsir merupakan hasil pengurangan antara luas bangun persegi panjang, luas persegi, dan luas segitiga. Lebih jelasnya, berikut hasil transkrip wawancara antara peneliti dengan subjek LK.

P : Ada berapa bangun yang terbentuk dalam butir soal 5? Apa saja?

LK : Ada 3 bangun, Pak, yaitu persegi panjang, persegi, dan segitiga.

P : Bagaimana proses menghitung luas daerah yang diarsir tersebut?

Alifmatika: Jurnal Pendidikan dan Pembelajaran Matematika, Desember 2021, Vol. 3, No. 2 
LK : Baik, Pak. Jadi, pertama saya mencari luas bangun yang diarsir dulu, itu dari bangun apa saja. Ternyata, luas bangun yang diarsir dari bangun persegi panjang dikurangi bangun persegi dikurangi bangun segitiga. Lalu, mencari luas bangun persegi panjang yang sudah diketahui panjang dan lebarnya, yaitu $35 \times 75=2.625 \mathrm{~m}^{2}$. Selanjutnya, mencari luas persegi $7 \times 7=49 \mathrm{~m}^{2}$. Terakhir, mencari luas segitiga $\frac{58 \times 30}{2}=870 \mathrm{~m}^{2}$. Kemudian, ditotal yaitu $2.625 \mathrm{~m}^{2}-49 \mathrm{~m}^{2}-870 \mathrm{~m}^{2}=1.600 \mathrm{~m}^{2}$. Begitu cara saya menghitungnya, Pak.

P : Mengapa bisa muncul angka Rp. 9.636.000?

LK : Karena uang tersebut digunakan untuk membeli rumput, Pak. Kan Dalam soal diketahui bahwa harga per meter adalah 6000, maka $1.600 \mathrm{~m}^{2} \times 6000$ hasil akhirnya Rp. 9.636.000.

$\mathbf{P} \quad$ : Yakin dengan jawaban kamu?

LK : Yakin, Pak.

Berdasarkan uraian transkrip di atas, diketahui bahwa subjek LK kurang teliti, sehingga terdapat kesalahan dalam memahami dan memberikan jawaban pada butir soal 5 . Hal ini menyebabkan subjek LK belum sepenuhnya melakukan tahapan objek dan tidak melakukan enkapsulasi dan de-enkapsulasi dengan baik. Hal ini mengakibatkan bahwa skema yang terbentuk belum sepenuhnya maksimal.

Tahapan yang sudah dijelaskan sebelumnya dalam beberapa tahapan pada teori APOS menujukkan bahwa subjek LK belum sepenuhnya melakukan tahapan dalam tahap aksi, meskipun pada tahapan proses sudah melakukan beberapa tahapan dengan baik dan benar. Pada tahapan objek juga belum sepenuhnya maksimal karena masih terdapat ketidak telitian subjek dalam menyelesaikan pengerjaan dengan benar, sehingga tahapan aksi, proses, objek dan skema, serta proses mekanisme mental belum sepenuhnya dilakukan dengan baik benar. Dengan demikian, pemahaman yang dimiliki oleh subjek KR dikategorikan ke dalam tingkat pemahaman instrumental, yang sesuai dengan Weyer (2010).

\section{KESIMPULAN}

Berdasarkan data dan temuan yang dipaparkan sebelumnya, 2 siswa dengan jenis kelamin berbeda, yaitu laki-laki dan rendah. Siswa perempuan dapat melakukan tahapan struktur dan mekanisme mental dan dalam teori APOS dengan lengkap dan maksimal, yang diawali dengan tahapan aksi dengan menentukan unsur-unsur bangun segiempat dan segitiga dan dapat menghitung kelilingnya, tahapan proses dan objek melalui mekanisme interiorisasi dan enkapsulasi dapat melakukan semua indikator dengan baik dan benar, serta de-enkapsulasi juga dilakukan dengan baik, sehingga abstraksi reflektif sudah terbentuk dan membentuk skema konsep segiempat dan segitiga yang termasuk dalam tingkat pemahaman relasional. Sementara itu, siswa laki-laki belum sepenuhnya melakukan tahapan dalam teori APOS dengan lengkap dan maksimal, yang mengakibatkan siswa tersebut belum memiliki pemahaman konsep matematika yang seutuhnya pada materi segiempat dan segitiga, sehingga pemamahamanya tergolong ke dalam tingkat pemahaman instrumental.

Alifmatika: Jurnal Pendidikan dan Pembelajaran Matematika, Desember 2021, Vol. 3, No. 2 


\section{DAFTAR PUSTAKA}

Anam, A. C., Juniati, D., \& Wijayanti, P. (2019). Understanding the Quadrilateral Concepts of Junior High School Students Based on APOS Theory in Terms of Differences in Cognitive Styles. In Mathematics, Informatics, Science, and Education International Conference (MISEIC 2019). (pp. 75-78). Atlantis Press.

Arnawa, I. M. (2009). Mengembangkan kemampuan mahasiswa dalam memvalidasi bukti pada aljabar abstrak melalui pembelajaran berdasarkan teori APOS. Jurnal Matematika Dan Sains, 14(2).

Arnon, I., Cottrill, J., Dubinsky, E., Oktaç, A., Fuentes, S. R., Trigueros, M., \& Weller, K. (2014). Apos theory: A framework for research and curriculum development in mathematics education. Apos Theory: A Framework for Research and Curriculum Development in Mathematics Education. https://doi.org/10.1007/9781461479666

Badraeni, N., Pamungkas, R. A., Hidayat, W., Rohaeti, E. E., \& Wijaya, T. T. (2020). Analisis Kesulitan Siswa Berdasarkan Kemampuan Pemahaman Matematik Dalam Mengerjakan Soal Pada Materi Bangun Ruang Sisi Datar. Jurnal Cendekia : Jurnal Pendidikan Matematika, 4(1), 247-253.

Barmby, P., Harries, T., Higgins, S., \& Suggate, J. (2007). How can we assess mathematical understanding? In Proceedings of the 31st Conference of the International Group for the Psychology of Mathematics Education (Vol. 2).

Haylock, D., \& Cockburn, A. D. (2008). Understanding mathematics for young children: A guide for foundation stage and lower primary teachers. United Kingdom: United Kingdom: SAGE Publication.

Helwig, R., Anderson, L., \& Tindal, G. (2001). Influence of elementary student gender on teachers' perceptions of mathematics achievement. Journal of Educational Research, 95(2). https://doi.org/10.1080/00220670109596577

Jafar. (2013). Membangun Pemahaman yang Lengkap (Completely Understanding) dalam Pembelajaran Konsep Grup. In Konferensi Nasional Pendidikan Matematika (KNPM) V, Himpunan Matematika Indonesia (pp. 87-95).

Khoiri, M. (2014). Pemahaman Siswa Pada Konsep Segiempat Berdasarkan Teori van Hiele. Prosiding Seminar Nasional Matematika.

Mardiyah, U. R. A., \& Budiarto, M. T. (2019). Abstraksi Reflektif dalam Mengonstruk Bangun Segiempat. MATHEdunesa, 8(3), 517-523.

Martínez-Planell, R., \& Cruz Delgado, A. (2016). The unit circle approach to the construction of the sine and cosine functions and their inverses: An application of APOS theory. Journal of Mathematical Behavior, 43. https://doi.org/10.1016/j.jmathb.2016.06.002

Piaget, J. (2014). Studies in Reflecting Abstraction. London: London: Psychology Press. https://doi.org/10.4324/9781315800509

Rofiki, I., Anam, A. C., Sari, P. E., Irawan, W. H., \& Santia, I. (2020). Students' Mental Construction in Cube and Cuboid Concept Based on Mathematics Ability Differences. Al-Jabar: Jurnal Pendidikan Matematika, 11(1), 133-144. 
Skemp, R. R. (2012). The Psychology of learning mathematics: Expanded American edition. The Psychology of Learning Mathematics: Expanded American Edition. https://doi.org/10.4324/9780203396391

Sutrisna, N., Pramuditya, S. A., Raharjo, J. F., \& Setiyani, S. (2021). Kemampuan Abstraksi Reflektif Matematis Siswa pada Materi Bangun Ruang. Journal of Didactic Mathematics, 2(1), 26-32.

Weyer, R. S. (2010). APOS theory as a conceptualization for understanding mathematical learning. Summation: Mathematics and Computer Science Scholarship at Ripon, 3, 9-15.

Wijaya, T. T., Ying, Z., \& Suan, L. (2020). Using Geogebra in Teaching Plane Vector. Journal of Innovative Mathematics Learning, 3(1), 15-23.

Wijaya, T. T., Dewi, N. S. S., Fauziah, I. R., \& Afrilianto, M. (2018). Analisis Kemampuan Pemahaman Matematis Siswa Kelas IX Pada Materi Bangun Ruang. UNION: Jurnal Ilmiah Pendidikan Matematika, 6(1), 19-28. https://doi.org/10.30738/.v6i1.2076

Wulandari, E. D., Hidayanto, E., \& Rahardi, R. (2019). Mathematical Representation of Cerebral Palsy Students in Constructing the Concept of Plane Geometry Based on APOS Theory. Ournal of Physics: Conference Series, 1227(1), 012018. 